\title{
Duodenal bacterial flora in early stages of transient monosaccharide intolerance in infants
}

\author{
ANNE M. KILBY, JEAN M. DOLBY, PAULINE HONOUR, AND J. A. WALKER-SMITH \\ From the Academic Department of Child Health, Queen Elizabeth Hospital for Children, London; and the \\ Division of Hospital Infection, Clinical Research Centre, Harrow
}

SUMMARY The aerobic and anaerobic bacterial flora of the duodenum were studied in 10 infants with transient monosaccharide intolerance. 5 infants had protracted diarrhoea after an episode of acute gastroenteritis and 5 had acute gastroenteritis. The duration of monosaccharide intolerance ranged from 1 to 20 days. Serial intubations were performed on 8 infants. In 5 of 8 cases the bacterial flora were of a normal type at the first intubation at $0-4$ days after the onset of monosaccharide intolerance. In 4 of those 5 patients there was an increase in bacterial count a few days later and anaerobes appeared. These findings are not consistent with the suggestion that monosaccharide intolerance is caused by abnormal bacteria in the upper small bowel.

Temporary disaccharide intolerance in infants is a frequent and well-recognized complication of acute gastroenteritis. Transient monosaccharide intolerance, however, is a much less common complication of either acute gastroenteritis or prolonged diarrhoeal illness. Transient monosaccharide intolerance in 4 infants was described by Burke and Danks (1966) and subsequent investigations of the small intestinal flora of 3 of these showed high counts of aerobic bacteria, up to $1010 / \mathrm{ml}$ in the duodenal juice during the episode of intolerance, while the presence of deconjugated bile salts suggested colonization of the small intestine with anaerobic bacteria as well (Gracey et al., 1969). Lifshitz and colleagues found many bacteria in the upper small intestine of infants with monosaccharide intolerance (Lifshitz et al., 1970; Coello-Ramírez et al., 1972). Anaerobic culture of duodenal juice was not performed in the above investigations but in a more recent study of infants with protracted diarrhoea, 1 of 2 infants with monosaccharide intolerance had a high bacterial count including anaerobes (Challacombe et al., 1974c).

It has been suggested by Gracey and colleagues that bacterial colonization of the small intestine of experimental animals and the consequent deconjugation of bile salts are factors in the impairment of monosaccharide absorption (Gracey et al., 1971b). If this is so in infants, it should be possible to culture abnormal numbers of bacteria from the duodenal juice at the onset of monosaccharide

Received 19 June 1976 intolerance, and these should include bacteria known to be capable of deconjugating bile salts such as certain anaerobes and Staphlycoccus aureus (Hill and Drasar, 1968). Previous reports specify that intubation was during or early in the episode of intolerance but none gives the exact time.

This investigation was prompted by our inability to grow any bacteria from the duodenal juice of an infant with sudden onset of monosaccharide intolerance. Not all the infants studied were similar to those with protracted diarrhoea described in previous reports. 5 of the infants had an acute episode of gastroenteritis. Most of the infants with protracted diarrhoea had a briefer episode of monosaccharide intolerance than the patients described by Burke and Danks (1966) and were not suffering from such severe malnutrition as the patients described by Lifshitz et al. (1970).

\section{Patients and methods}

Patients. The 8 male and 2 female infants in this study were all born in Britain and were aged 2-16 months. All were intolerant to glucose, and 6 out of the 7 to whom it was given were intolerant to fructose (see Table 1).

Group I. Cases 1-5 had protracted diarrhoea and poor weight gain for some weeks after an episode of acute gastroenteritis. All had a prolonged stay in hospital and had been observed to be tolerant to 
Table 1 Details of 10 cases with monosaccharide intolerance

\begin{tabular}{|c|c|c|c|c|c|c|c|c|c|}
\hline Case no. & $\operatorname{Sex}$ & Age & Diagnosis & $\begin{array}{l}\text { Stool } \\
\text { bacteria* } \\
\text { isolated }\end{array}$ & $\begin{array}{l}\text { Virus } \\
\text { identified }\end{array}$ & $\begin{array}{l}\text { Glucose } \\
\text { intolerant }\end{array}$ & $\begin{array}{l}\text { Fructose } \\
\text { intolerant }\end{array}$ & $\begin{array}{l}\text { Previously } \dagger \\
\text { tolerant }\end{array}$ & $\begin{array}{l}\text { Duration of } \ddagger \\
\text { intolerance }(d)\end{array}$ \\
\hline \multicolumn{10}{|l|}{ Group I } \\
\hline & $\mathbf{M}$ & $9 \mathrm{w}$ & $\begin{array}{l}\text { Delayed recovery } \\
\text { from } \\
\text { gastroenteritis }\end{array}$ & None & Reovirus & Yes & Yes & Yes & 8 \\
\hline 2 & $\mathbf{F}$ & $6 \mathrm{~m}$ & $\begin{array}{l}\begin{array}{c}\text { Delayed recovery } \\
\text { from }\end{array} \\
\text { gastroenteritis; } \\
\text { autoimmune } \\
\text { haemolytic } \\
\text { anaemia }\end{array}$ & ", & Reovirus & $"$ & " & ", & 20 \\
\hline 3 & $\mathbf{M}$ & $2 \mathrm{~m}$ & $\begin{array}{l}\text { Delayed recovery } \\
\text { from } \\
\text { gastroenteritis }\end{array}$ & ", & Not studied & " & & ", & 1 \\
\hline 4 & $\mathbf{M}$ & $2 \mathrm{~m}$ & $\begin{array}{l}\text { Delayed recovery } \\
\text { from } \\
\text { gastroenteritis; } \\
\text { hydrocephalus }\end{array}$ & $\begin{array}{l}\text { Ps. } \\
\quad \text { aeruginosa }\end{array}$ & Not studied & $"$ & $"$ & $"$ & 22 \\
\hline 5 & $\mathbf{M}$ & $7 w$ & $\begin{array}{l}\text { Delayed recovery } \\
\text { from } \\
\text { gastroenteritis }\end{array}$ & E. coli $\mathbf{O S S}$ & Not seen & ", & $"$ & $"$ & 2 \\
\hline$\underset{6}{\text { Group } I I}$ & $\mathbf{F}$ & $4 \mathrm{~m}$ & $\begin{array}{l}\text { Acute } \\
\text { gastroenteritis }\end{array}$ & None & $\begin{array}{c}\text { Coxsackie } \\
\text { A21 }\end{array}$ & $"$ & No & No & 1 \\
\hline $\begin{array}{r}7 \\
8 \\
9 \\
10\end{array}$ & $\begin{array}{l}\mathbf{M} \\
\mathbf{M} \\
\mathbf{M} \\
\mathbf{M}\end{array}$ & $\begin{array}{r}3 \mathrm{~m} \\
8 \mathrm{~m} \\
13 \mathrm{~m} \\
16 \mathrm{~m}\end{array}$ & $\begin{array}{l}", \\
",\end{array}$ & $\begin{array}{l}", \\
\text { E. coli } 0111\end{array}$ & $\begin{array}{c}\text { Reovirus } \\
\text { Not studied } \\
\text { ", } \\
\text { ", }\end{array}$ & $\begin{array}{l}\text { ", } \\
\text { ", } \\
\text { ", }\end{array}$ & $\begin{array}{l}\text { Yes } \\
\text { Yes }\end{array}$ & $\begin{array}{l}\text { No } \\
\text { Yes } \\
\text { No } \\
\text { Yes }\end{array}$ & $\begin{array}{l}3 \\
5 \\
3 \\
2\end{array}$ \\
\hline
\end{tabular}

*E. coli of enteropathogenic serotype and other Enterobacteriaceae only listed; 'none' indicates absence of these groups. tObserved in hospital to be monosaccharide tolerant before episode of intolerance.

$\ddagger$ No. of days from detection of monosaccharide intolerance until monosaccharide tolerated again.

monosaccharide-containing feeds before the episode of intolerance.

Group II. Cases 6-10 were admitted with a diagnosis of acute gastroenteritis and in each case recovery was delayed by transient monosaccharide intolerance.

Stools. Specimens from all patients were examined regularly for enteropathogenic $E$. coli and from 5 patients for virus particles. Duodenal juice from each patient was examined for Giardia lamblia.

From the time of admission of each patient, loose or watery stools were tested for reducing substances. The first day monosaccharide intolerance occurred was designated day 0. For Cases 6, 7, and 9, day 0 was the first day that monosaccharide intolerance was detected. Since no period of monosaccharide tolerance was observed in hospital it is possible that intolerance had been present before admission.

Diagnosis of monosaccharide intolerance. This was based on the following criteria. (1) Watery diarrhoea while on an oral feed containing monosaccharide, either glucose or fructose, as the only carbohydrate. The stool fluid contained on at least two occasions a significant amount of reducing substances, i.e. $0.5 \%$ or more by the Clinitest method (Kerry and Anderson, 1964). The presence of the monosaccharide in the stool fluid was confirmed by paper chromatography. (2) Immediate cessation of the diarrhoea when carbohydrate was removed from the oral feeds. For Cases 3 and 6 this was not done. Though glucose intolerance occurred, Case 3 did not become dehydrated and the same feeds containing glucose were continued; the diarrhoea settled spontaneously during the next few days. For Case 6 the oral carbohydrate was changed from $5 \%$ glucose to $2 \%$ glucose with $2 \%$ fructose and the diarrhoea ceased.

All other infants were placed on a feed completely free from carbohydrate for periods varying from 24 hours to 11 days. The fluid by mouth was either an electrolyte solution or a feed containing comminuted chicken meat and electrolytes. When the infant was sufficiently improved clinically, monosaccharide in the feeds was tried again. This was always reintroduced starting at a low concentration such as $1 \%$ of either glucose or fructose or in combination and was tolerated at the first trial by all except Case 4 .

Duodenal intubation. This was carried out as soon as possible after the onset of monosaccharide intoler- 
ance. None of the infants had been fed previously via a nasogastric tube. Intubation was performed at least $\mathbf{2}$ hours and usually more than $\mathbf{4}$ hours after the last feed to avoid the post prandial increase of bacterial count (Drasar et al., 1969). Intubation was performed with a fresh piece of polyvinyl tube weighted with a paediatric Crosby biopsy capsule which had been previously disinfected in a solution of $0.5 \%$ chlorhexidine in methylated spirit. In most instances the position of the capsule was checked radiographically with an image intensifier, so that the capsule lay in the 3rd or 4th part of the duodenum. The tubing was flushed with $2 \mathrm{ml}$ sterile saline, cleared with air, and a sample of juice collected about 10 minutes later. When $x$-ray screening of the infant was not justified, a specimen of juice was collected after a good flow of clear bile-stained alkaline fluid was obtained. Samples were collected within 90 minutes of the infant swallowing the capsule to avoid the effects of prolonged intubation (Challacombe et al., 1974a).

Bacteriological investigation. Juice for bacteriological culture was collected without air bubbles into a sterile syringe and immediately $0.1 \mathrm{ml}$ of juice was inoculated into $0.9 \mathrm{ml} 10 \%$ glycerol-broth transport medium, gently mixed without aeration, frozen immediately in solid $\mathrm{CO}_{2}$ and stored in this way or at $-30^{\circ} \mathrm{C}$ until cultured 4-24 hours later. Quantitative investigation of aerobic and anaerobic bacteria was performed by methods developed by Drasar (1967) and modified by Hewitt and Rigby (1976). Classification was according to Cowan and Steel (1965). For only half the bacteria classified as 'anaerobic' were the attempts to subculture successful; for the others identification was based on initial colony characteristics and bacterial morphology and made only when a fair degree of certainty existed.

No patient had been given antibiotics within 10 days of the first intubation. Case 8 had completed a 5 -day course of ampicillin 3 days before the second intubation.

Small-intestinal biopsy. This was performed on 6 patients. The mucosa was examined histologically and graded by the following system: $\mathrm{N}=$ normal; $+=$ mild partial villous atrophy; $++=$ severe partial villous atrophy; $+++=$ flat mucosa.

Disaccharidases. These were estimated in the mucosal specimens by a modification of the method of Burgess et al. (1964) and results are expressed as: $\mathbf{N}=$ normal; $\downarrow=$ activity of at least two disaccharidases below the normal range.

\section{Results}

Five infants were first intubated within 48 hours of the onset of monosaccharide intolerance, 3 at 3-4 days, and 2 later at 15 and 24 days. At the time of the first intubation 7 were intolerant and 3 were just into the recovery phase. The timing of intubation, the state of the intestinal mucosa, total bacterial counts of the duodenal juice, and the presence of bacteria capable of deconjugating bile salts are given in Table 2. In 5 of 7 infants intubated while still intolerant, the total bacterial count was $<10^{4}$ organisms $/ \mathrm{ml}$ juice, the level which we have taken as the upper limit of normal (see Discussion). Details of the organisms grown from the duodenal juice and the numbers cultured are given in Table 3.

In Cases $1,3,8$, and 9 bacteria known to be capable of deconjugating bile salts, i.e. Staph. aureus, Bacteroides sp., or Veillonella sp. were not found in the duodenal juice at the time of intolerance; in fact, there was no growth at all in the first specimens from Cases 3 and 8. However, 'deconjugating' bacteria were present in variable amounts during the recovery phase of the illness in these 4 patients.

Veillonella sp. was numerous in Case 5 at day 1, and Staph. aureus was present in Case 10 at the time of onset of monosaccharide intolerance. Case 6 had Staph. aureus and a low count of Bacteroides sp. at day 1, and Case 7 a low count of Bacteroides sp. on day 4 , but both were already becoming monosaccharide tolerant at the time.

The Fig. shows the total of aerobic and anaerobic bacteria for 8 infants on whom more than one intubation was done and shows the increase in Cases $1,3,6,8$, and 9 . In Case 10 the bacterial count fell. In Cases 5 and 7 the bacterial count fell but these infants were not intubated on day 0 .

$E$. coli was isolated from the duodenal juice of 4 infants but was not of a recognized enteropathogenic serotype. Cases 5 and 10 both excreted enteropathogenic $E$. coli in the stools but $E$. coli was not present in the duodenal juice. Case 4 excreted Pseudomonas aeruginosa which was not found in the duodenal juice. Giardia was not found in any patient.

\section{Discussion}

Dawson and Isselbacher (1960) found that glucose transport across the small intestinal epithelium of animals was inhibited by free bile acids but not by conjugated bile salts. Tabaqchali and Booth (1966) found that bacterial overgrowth in the small intestine and the presence of deconjugated bile salts were associated. Bacteria capable of conjugating bile salts were identified by Hill and Drasar (1968). Gracey and his colleagues showed a relationship between 
Table 2 Biopsy findings, disaccharidase levels, and bacteria in duodenal juice of 10 cases

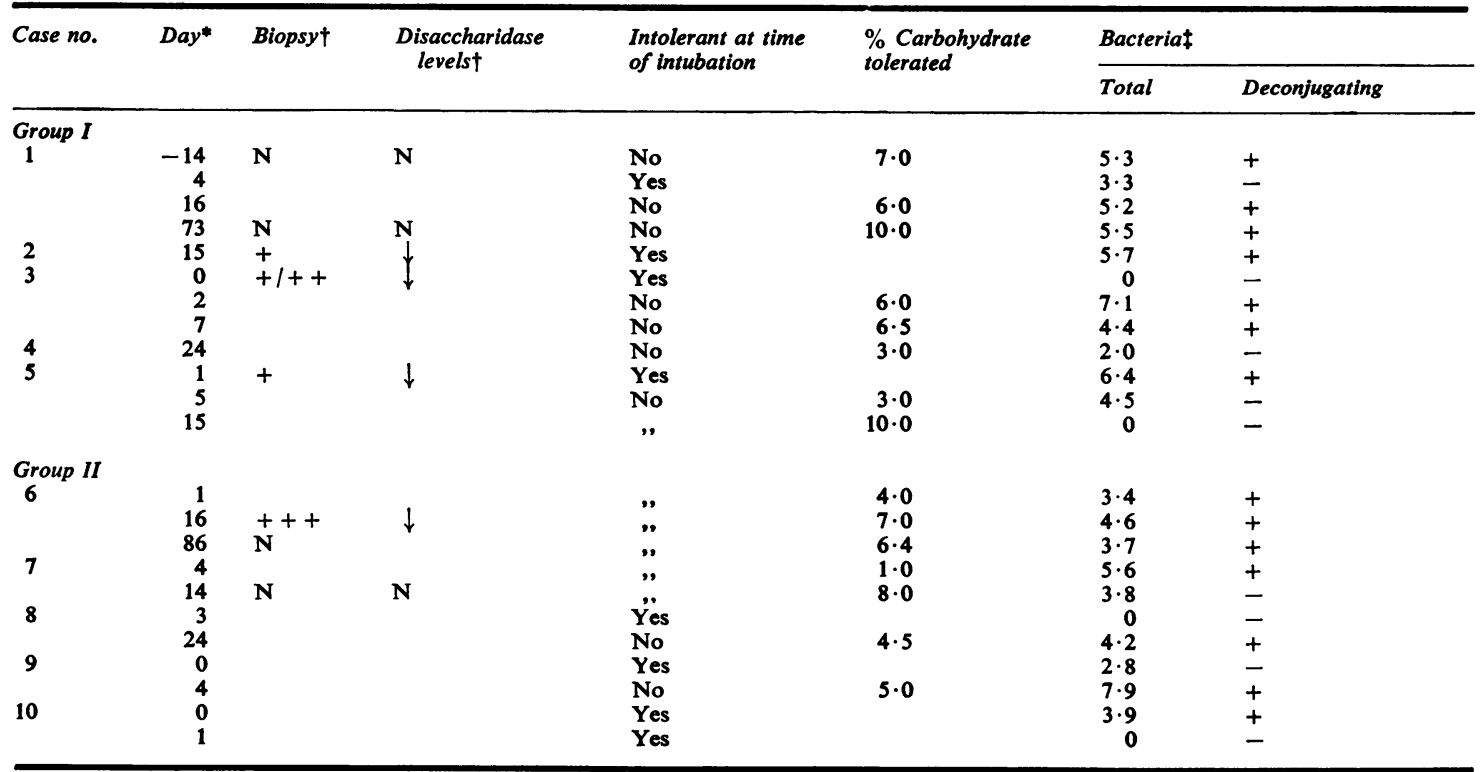

-Day of intubation: Day 0 is day of onset of monosaccharide intolerance.

$+\mathrm{N}=$ normal; $+=$ mild partial villous atrophy; $++=$ severe; $+++=$ flat mucosa; $\downarrow=$ activity of at least 2 disaccharidases below normal range.

$\ddagger$ For detailed analysis see Table 3. Total: Number $\log _{10} / \mathrm{ml}$ of duodenal juice. Fewer bacteria than $10^{2} / \mathrm{ml}$ are undetected and expressed as 0 . Deconjugatings $<10^{2}$ organisms/ml expressed as - , otherwise as + .
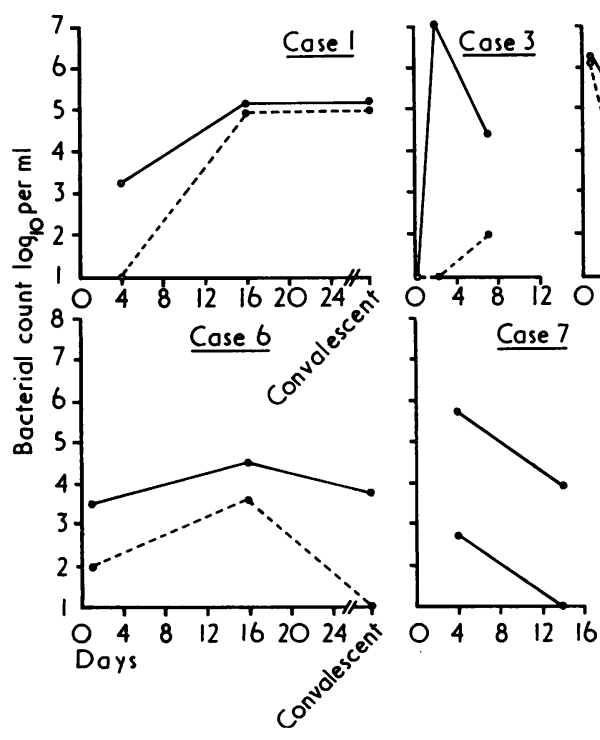

$\begin{array}{llllllll}0 & 4 & 8 & 12 & 16 & 0 & 2\end{array}$
Cose 5
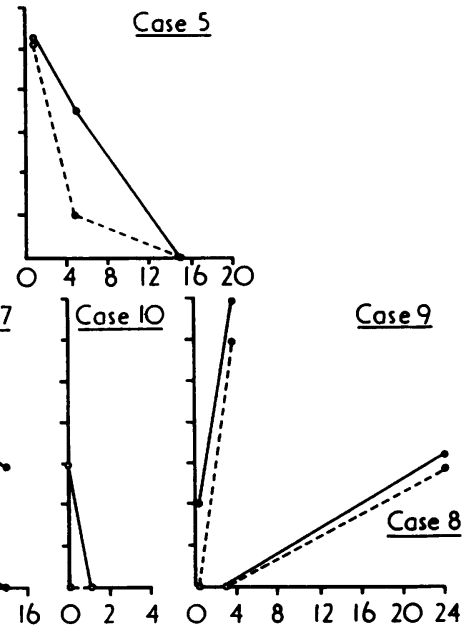

Fig. Bacteria in the duodenal juice of infants with monosaccharide intolerance. Solid line $=$ total aerobic bacteria; broken line $=$ total anaerobic bacteria; $0=$ infant monosaccharide intolerant; $\bullet=$ infant monosaccharide tolerant. bacterial colonization, the deconjugation of bile salts, and impairment of glucose absorption in vivo in the rat (1971b). They also showed (Gracey et al., 1971a) that the impairment of glucose absorption by intesti- nal mucosa in vitro was readily reversible and that cell damage was not permanent. Their suggestion (Gracey and Burke, 1973) that monosaccharide intolerance in infants may result from the action of 
Table 3 Bacteria found in duodenal juice of 10 patients with monosaccharide intolerance

\begin{tabular}{|c|c|c|c|c|c|c|c|c|c|c|c|c|}
\hline \multirow[b]{3}{*}{ Case no. } & \multirow[b]{3}{*}{$\begin{array}{l}\text { Day of } \\
\text { intolerance }\end{array}$} & \multicolumn{11}{|c|}{ No. $\left(\log _{10}\right)$ of bacteria/ml juice } \\
\hline & & \multicolumn{7}{|c|}{ Aerobic } & \multicolumn{4}{|c|}{ Anaerobic } \\
\hline & & : & 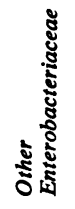 & 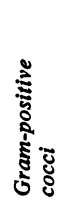 & 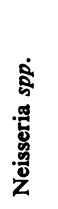 & 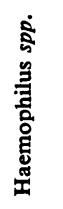 & 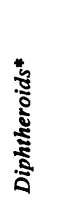 & 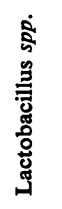 & 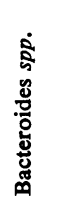 & 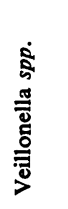 & 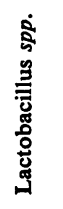 & 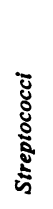 \\
\hline 1 & $\begin{array}{r}-14 \\
4 \\
16 \\
73\end{array}$ & $\begin{array}{l}4 \cdot 6 \\
2 \cdot 3\end{array}$ & $4 \cdot 9$ & $\begin{array}{l}5 \cdot 1 \ddagger \\
3 \cdot 3 \\
3 \cdot 0 \\
5 \cdot 0\end{array}$ & $3 \cdot 0$ & $\begin{array}{l}4 \cdot 3 \\
3 \cdot 0\end{array}$ & $\begin{array}{l}4 \cdot 4 \\
3 \cdot 7 \\
4 \cdot 0\end{array}$ & & $\begin{array}{l}4 \cdot 0 \\
4 \cdot 8\end{array}$ & & $\begin{array}{l}4 \cdot 5 \\
4 \cdot 0 \\
3 \cdot 0\end{array}$ & $4 \cdot 8$ \\
\hline 2 & 15 & $4 \cdot 2$ & & $5 \cdot 7 \ddagger$ & $4 \cdot 0$ & & & & $3 \cdot 0$ & & $3 \cdot 0$ & \\
\hline 3 & $\begin{array}{l}0 \\
2 \\
7\end{array}$ & & $3 \cdot 0$ & $\begin{array}{l}\text { No ba } \\
7 \cdot 1 \ddagger \\
4 \cdot 6\end{array}$ & eria is & ted & & $3 \cdot 5$ & & $2 \cdot 0$ & & \\
\hline $4 \dagger$ & 24 & & & $2 \cdot 0$ & & & & & & & & \\
\hline 5 & $\begin{array}{r}1 \\
5 \\
15\end{array}$ & & & $\begin{array}{l}5 \cdot 8 \\
4 \cdot 1 \\
\text { No ba }\end{array}$ & $\begin{array}{l}4 \cdot 2 \\
\text { eria is }\end{array}$ & $\begin{array}{l}4 \cdot 3 \\
2 \cdot 3 \\
\text { ted }\end{array}$ & $\begin{array}{l}4 \cdot 3 \\
3 \cdot 8\end{array}$ & $\begin{array}{l}5 \cdot 8 \\
2 \cdot 3\end{array}$ & & $6 \cdot 0$ & $2 \cdot 0$ & \\
\hline 7 & $\begin{array}{r}1 \\
16 \\
86 \\
4\end{array}$ & $3 \cdot 5$ & $\begin{array}{l}2 \cdot 6 \\
2 \cdot 6\end{array}$ & $\begin{array}{l}3 \cdot 4 \ddagger \\
4 \cdot 4 \ddagger \\
3 \cdot 6 \ddagger \\
3 \cdot 8\end{array}$ & $\begin{array}{l}2 \cdot 8 \\
3 \cdot 7 \\
3 \cdot 3\end{array}$ & $\begin{array}{l}2 \cdot 6 \\
3 \cdot 6 \\
2 \cdot 7 \\
5 \cdot 6\end{array}$ & & $2 \cdot 0$ & $\begin{array}{l}2 \cdot 0 \\
2 \cdot 6\end{array}$ & & & $3 \cdot 6$ \\
\hline & 14 & & $2 \cdot 7$ & $3 \cdot 5$ & $3 \cdot 3$ & $2 \cdot 7$ & & & & & & \\
\hline 8 & $\begin{array}{r}3 \\
24\end{array}$ & $2 \cdot 5$ & $2 \cdot 5$ & $\begin{array}{l}\text { No ba } \\
\mathbf{3 . 0}\end{array}$ & $\begin{array}{l}\text { eria is } \\
3 \cdot 8\end{array}$ & $\begin{array}{l}\text { ted } \\
3 \cdot 0\end{array}$ & & & & $3 \cdot 8$ & & \\
\hline 9 & $\begin{array}{l}0 \\
4\end{array}$ & & $4 \cdot 0$ & $\begin{array}{l}2 \cdot 8 \\
7 \cdot 0\end{array}$ & $5 \cdot 5$ & $2 \cdot 0$ & & $6 \cdot 0$ & $5 \cdot 7$ & & $5 \cdot 3$ & $6 \cdot 6$ \\
\hline 10 & $\begin{array}{l}0 \\
1\end{array}$ & & $3 \cdot 7$ & $\begin{array}{l}3 \cdot 5 \ddagger \\
\text { No ba }\end{array}$ & eria is & & & & & & & \\
\hline
\end{tabular}

*Usually require additional $\mathrm{CO}_{2}$.

+Candida sp. also present.

$\ddagger$ Staph. aureus present.

deconjugated bile salts produced by small intestinal bacteria postulates abnormal bacterial colonization at the onset of intolerance.

In two previous reports the degree of bacterial colonization of the small bowel tended to parallel the severity of the sugar intolerance (Gracey et al., 1969; Coello-Ramírez et al., 1972). Using a consistent technique we made the unexpected observation, however, that in 5 infants still in the monosaccharide intolerant phase of their illness the bacterial counts were within the normal range. This we have taken as $<10^{4}$ organisms $/ \mathrm{ml}$, based on adult figures (Gorbach, 1971) and on our own observations on a small number of children without gastrointestinal disease. Thus impairment of monosaccharide absorption in these 5 at least occurred in the apparent absence of bacterial colonization of the duodenum, and in 4 of these in the absence of bacteria capable of deconjugating bile salts. Subsequently the bacterial count increased considerably in 4 of these 5 infants. At some time in their illness a bacterial count of well over $10^{4}$ organisms $/ \mathrm{ml}$ duodenal juice was found in 6 of our patients. Deconjugating organisms were isolated from cases $1,3,8$, and 9 only later in the illness as the total bacterial count increased from normal to abnormal levels, and was associated with an improvement in monosaccharide tolerance rather than the reverse.

Our patients, however, are not exactly comparable to those in either of two previous reports. Those described by Gracey and colleagues, though similar to our patients in group I, all had a more prolonged episode of monosaccharide intolerance. The majority of patients described by Coello-Ramírez et al. 
(1972) suffered from chronic diarrhoea with marasmus or kwashiorkor. Such infants often have many bacteria in the jejunum (Hayworth and Brown, 1975) which may be important in the pathogenesis of their illness. The pathogenic importance or otherwise of bacteria in the small bowel of previously well-nourished London-born infants may be very different.

It is difficult to compare the results of bacteriological investigations reported by various authors because of differences in the technique of collecting, storing, and culturing of specimens. Freezing the specimens before culturing can be responsible for a 10 - to 100-fold loss in indigenous organisms; in particular some of the Enterobacteriaceae including E. coli. Gram-positive cocci, Neisseria sp., and some Haemophilus sp. were usually unaffected (J. M. Dolby and P. Honour, unpublished), but the fate of anaerobic bacteria is unknown. When bacteria from an in vitro culture were added to small intestinal juice and then frozen there was no loss of viability (Drasar, et al., 1969). With fluid of so variable a composition as duodenal juice, survival of bacteria in it during freezing may vary from specimen to specimen and at different stages of diarrhoeal illness in a particular infant.

Rapid intestinal transit time causing bacterial 'wash-out' could be a contributory cause of the low bacterial counts. We do not have comprehensive data but in Cases 5 and 10 the bacterial count fell as the diarrhoea improved. Gorbach et al. (1970) were able to show that in normal adults the bacterial count in the small intestine rose during experimentally induced diarrhoea.

A disadvantage of the described method of collecting a specimen of juice from the duodenum is that only one level of the small intestine is sampled. Even though the duodenum is sterile or contains only normal numbers of bacteria, the small intestine may be abnormally contaminated lower down. This problem can be solved only by sampling at multiple levels but the prolonged intubation time required is of questionable justification.

Thus although in previous reports monosaccharide intolerance was associated with bacterial colonization of the duodenum, we were unable to confirm this association in several patients. In view of the rapid recovery, with respect to monosaccharide transport, of intestinal mucosa exposed to bile acids (Gracey et al., 1971a) damage during earlier bacterial colonization is unlikely to be the cause. We suggest that transient monosaccharide intolerance may be the result of several factors acting together in the small intestine at a particular time. These might include the presence of pathogenic bacteria or viruses, the action of entero- toxin, bowel motility, and transit time, and the extent and severity of any mucosal lesion. In 3 of our cases with protracted diarrhoea we showed a histological abnormality of the small intestinal mucosa and depressed disaccharidase activity. It has already been shown that during acute gastroenteritis in infants severe mucosal damage may be present (Barnes and Townley, 1973).

In any future attempts to link transient monosaccharide intolerance in infants with bacterial colonization of the upper small intestine and abnormal deconjugation of bile salts, not only should the bacteria be counted and identified, but their ability to deconjugate bile salts and the presence of free bile acids in the duodenal juice should be investigated. Challacombe et al. (1974b) were unable to find deconjugated bile salts in the duodenal juice from a single intubation of an infant with secondary monosaccharide intolerance, though high counts of Bacteroides sp. were found. Our study makes it clear that investigations should be done at the onset of intolerance and followed by serial estimations. It is essential that the timing of these be carefully recorded with relation to the onset and continued presence of the monosaccharide intolerance.

We are grateful to Dr. R. Bird for reovirus identification by electron microscopy; to Dr. N. E. France for histological reports; to Mr. V. C. Oberholzer for paper chromatography; to Dr. Bo Yap for clinical assistance; to Professor C. B. S. Wood and Dr. B. Laurance for allowing us to include patients under their care; and to Mrs. E. Lister for secretarial work. A. M. K. was supported by the Heinz Research Fund and the Research Appeal Trust of the Queen Elizabeth Hospital.

\section{References}

Barnes, G. L., and Townley, R. R. W. (1973). Duodenal mucosal damage in 31 infants with gastroenteritis. Archives of Disease in Childhood, 48, 343-349.

Burgess, E. A., Levin, B., Mahlanabis, D., and Tonge, R. E. (1964). Hereditary sucrose intolerance: levels of sucrase activity in jejunal mucosa. Archives of Disease in Childhood, 39, 431-443.

Burke, V., and Danks, D. M. (1966). Monosaccharide malabsorption in young infants. Lancet, 1, 1177-1180.

Challacombe, D. N., Richardson, J. M., and Anderson, C. M. (1974a). Bacterial microflora of the upper gastrointestinal tract in infants without diarrhoea. Archives of Disease in Childhood, 49, 264-269.

Challacombe, D. N., Richardson, J. M., and Edkins, S. (1974b). Anaerobic bacteria and deconjugated bile salts in the upper small intestine of infants with gastrointestinal disorders. Acta Paediatrica Scandinavica, 63, 581-587.

Challacombe, D. N., Richardson, J. M., Rowe, B., and Anderson, C. M. (1974c). Bacterial microflora of the upper gastrointestinal tract in infants with protracted diarrhoea. Archives of Disease in Childhood, 49, 270-277. 
Coello-Ramírez, P., Lifshitz, F., and Zuniga, V. (1972). Enteric microflora and carbohydrate intolerance in infants with diarrhea. Pediatrics, 49, 233-242.

Cowan, S. T., and Steel, K. J. (1965). Manual for the Identification of Medical Bacteria. Cambridge University Press, London.

Dawson, A. M., and Isselbacher, K. J. (1960). Studies on lipid metabolism in the small intestine with observations on the role of bile salts. Journal of Clinical Investigation, 39, 730-740.

Drasar, B. S. (1967). Cultivation of anaerobic intestinal bacteria. Journal of Pathology and Bacteriology, 94, 417-427.

Drasar, B. S., Shiner, M., and McLeod, G. M. (1969). Studies on the intestinal flora. 1. The bacterial flora of the gastrointestinal tract in healthy and achlorhydric persons. Gastroenterology, 56, 71-79.

Gorbach, S. L. (1971). Intestinal microflora. Gastroentero$\log y, 60,1110-1129$.

Gorbach, S. L., Neale, G., Levitan, R., and Hepner, G. W. (1970). Alterations in human intestinal microflora during experimental diarrhoea. Gut, 11, 1-6.

Gracey, M., and Burke, V. (1973). Sugar-induced diarrhoea in children. Archives of Disease in Childhood, 48, 331-336.

Gracey, M., Burke, V., and Anderson, C. M. (1969). Association of monosaccharide malabsorption with abnormal small-intestinal flora. Lancet, 2, 384-385.

Gracey, M., Burke, V., and Oshin, A. (1971a). Reversible inhibition of intestinal active sugar transport by deconju- gated bile salts in vitro. Biochimica et Biophysica Acta, 225, 308-314.

Gracey, M., Burke, V., Oshin, A., Barker, J., and Glasgow, E. F. (1971b). Bacteria, bile salts and intestinal monosaccharide malabsorption. Gut, 12, 683-692.

Hewitt, J., and Rigby, J. (1976). Effect of various milk feeds on numbers of Escherichia coli and Bifidobacterium in the stools of newborn infants. Journal of Hygiene, 77, 129-139.

Heyworth, B., and Brown, J. (1975). Jejunal microflora in malnourished Gambian children. Archives of Disease in Childhood, 50, 27-33.

Hill, M. J., and Draser, B. S. (1968). Degradation of bile salts by human intestinal bacteria. Gut, 9, 22-27.

Kerry, K. R., and Anderson, C. M. (1964). A ward test for sugar in faeces. Lancet, 1, 981-982.

Lifshitz, F., Coello-Ramírez, P., Gutiérrez-Topete, G., and Gutiérrez, M. L. C. (1970). Monosaccharide intolerance and hypoglycemia in infants with diarrhea. 1. Clinical course of 23 infants. Journal of Pediatrics, 77, 595-603.

Tabaqchali, S., and Booth, C. C. (1966). Jejunal bacteriology and bile-salt metabolism in patients with intestinal malabsorption. Lancet, 2, 12-15.

Correspondence to Dr. Anne Kilby, Paediatric Department, University College Hospital, Gower Street, London WC1. 